\title{
Isolation and Identification of a Potential Amylolytic Probiotic Bacterium from the Gut of Jundiá Catfish, Rhamdia quelen.
}

\author{
Tatiana Vieira Poletto ${ }^{1}$, Cleide Rosana Werneck Vieira ${ }^{2}$, Carlos Peres Silva ${ }^{3}$, Debora \\ Machado Fracalossi ${ }^{1 *}$; \\ ${ }^{1}$ Federal University of Santa Catarina - Aquaculture Department; ${ }^{2}$ Universidade Federal de Santa Catarina $\checkmark$ - \\ Department of Food Science and Technology; ${ }^{3}$ Universidade Federal de Santa Catarina $\checkmark$ - Biochemistry
}

\begin{abstract}
This study aimed to isolate a potential probiotic amylolytic strain from the gut of jundiá catfish to improve carbohydrate digestibility in fish. Two of 31 strains isolated from the foregut of Rhamdia quelen were able to grow on starch-agar medium and were considered amylolytic. The strain that presented higher amylolytic potential, based on a qualitative amylase assay, was chosen. The strain was phenotypically characterized and analysed to determine bile and $\mathrm{pH}$ tolerance and extracellular quantitative amylase activity. The probiotic candidate, identified as Aeromonas veronii, showed the ability to survive stresses from a range of $\mathrm{pH}$ and bile salt conditions and secreted an interesting enzymatic profile, which may exhibit a synergistic effect when combined with the enzymes secreted by the jundiá catfish, improving carbohydrate digestion in the host. The results demonstrated the potential of $A$. veronii to improve the digestion process in jundiá by providing exogenous enzymes for the breakdown and absorption of nutrients.
\end{abstract}

Keywords: enzymes, probiotics, aquaculture, intestinal microbiology, Aeromonas veronii

\footnotetext{
* Author for correspondence: debora.fracalossi@ufsc.br
} 


\section{INTRODUCTION}

Feed production for aquaculture remains dependent on expensive protein-rich ingredients to meet the nutritional requirements of fish ${ }^{1,2}$. Nutritional requirements and capacity to utilize diverse ingredients vary according to fish gut physiology and morphology ${ }^{1,3}$, making the search for alternative ingredients difficult for some fish species.

Carbohydrate is an interesting type of macronutrient that can be included in formulated diets as a source of energy, representing an efficient way to decrease costs and contribute to the protein-sparing effect ${ }^{4,5}$. However, there is no evidence of specific dietary requirement for carbohydrate in fish ${ }^{6}$, and fish do not use dietary carbohydrate as efficiently as terrestrial animals.

The jundiá catfish Rhamdia quelen is widely distributed and is a species of interest in the aquaculture sector in Brazil, Uruguay and Argentina. This fish species is a good model for carbohydrate utilization, as despite its omnivore feeding habits, it exhibits a short intestine, which hinders dietary carbohydrate utilization ${ }^{7-9}$ compared with other typical omnivores such as Nile tilapia (Oreochromis niloticus) ${ }^{3,9}$.

Probiotic bacteria play roles in the digestive and nutritional processes of aquatic animals ${ }^{10}$ through the production of enzymes ${ }^{11}$. There is vast potential for research linked to the use of these enzyme-producing bacteria to the increase feed efficiency and, consequently, improve the growth of the host. Therefore, the aim of this study was to isolate a probiotic strain with amylolytic potential from a native freshwater fish (R. quelen) to improve carbohydrate digestibility.

\section{MATERIAL AND METHODS}

\section{Preparation of the Foregut from Jundiá Catfish}

Ten female jundiá catfish $(95.45 \pm 6.66 \mathrm{~g})$ were starved for $48 \mathrm{~h}$ to clean the gastrointestinal tract before dissection ${ }^{14}$. All of the fish were sacrificed through a sharp blow to the head, and their proximal intestine (foregut) was removed aseptically, then cut into pieces and flushed three times using a syringe with a chilled sterile $0.9 \%$ sodium chloride solution. The proximal intestines were homogenized in the chilled sterile $0.9 \%$ $\mathrm{NaCl}$ solution ${ }^{15}$ with a sterile mortar. All of the procedures used in the present study complied with the guidelines for animal care of the local Ethics Committee on the Use of Animals (CEUA-UFSC, protocol number PP00815).

\section{Detection of Amylase-Producing Bacteria}

The foregut homogenate was used after 10-fold dilutions were obtained, which were spread in triplicate aliquots $(100 \mu \mathrm{l})$ on tryptic soy agar (TSA) to characterize the total viable counts of autochthonous aerobic bacteria. The plates were incubated at $32{ }^{\circ} \mathrm{C}$ for $24 \mathrm{~h}$, and colonies were purified by streaking ${ }^{14}$ and then transferred to starch-agar medium (SA) ${ }^{16}$, followed by incubation at $32{ }^{\circ} \mathrm{C}$ for $24 \mathrm{~h}$. The strains that grew under these conditions were considered amylolytic ${ }^{17}$.

\section{Determination of Possible Harmful Effects of the Bacterial Isolates on the Host}

To verify that the selected isolates were not pathogenic to the host, 36 juveniles of jundiá $(28.4 \pm 5.0 \mathrm{~g})$ were stocked in three aquaria $(50 \mathrm{~L}$ glass; one for each treatment, 
Isolation of a probiotic bacterium

consisting of the two probiotic candidates and the control), with $70 \%$ daily water exchange, continuous aeration and a constant temperature $\left(28^{\circ} \mathrm{C}\right)$ for $120 \mathrm{~h}$.

Both probiotic candidates were grown in tryptic soy broth medium (TSB) in a shaking incubator at $32{ }^{\circ} \mathrm{C}$ overnight. After incubation, the cells were harvested via centrifugation ( $5000 \mathrm{~g}, 5 \mathrm{~min}$ ), washed twice in sodium chloride solution and resuspended in the same sterile saline solution. Dilution plating was used to verify the relationship between the $\mathrm{OD}_{600}$ and the number of colony-forming units $(\mathrm{CFU})$ per millilitre. The absorbance at $600 \mathrm{~nm}$ was adjusted to $0.60 \pm 0.05$ to standardize the

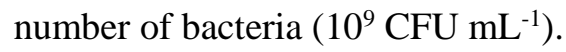

All fish were inoculated intraperitoneally with $0.1 \mathrm{~mL}$ of saline containing $10^{9} \mathrm{CFU}$ $\mathrm{mL}^{-1}$ of respective selected isolate, except for the control group, which was injected with sterile phosphate-buffered saline (PBS) alone. During the experiment, the behaviour of the fish was monitored, and after $120 \mathrm{~h}$, all fish were sacrificed as described above, and their organs were examined for evidence of disease. To check for the presence of the respective probiotic candidate strain, swabbed materials from the peritoneal cavity and kidneys of all fish were inoculated onto TSA and incubated at 32 ${ }^{\circ} \mathrm{C}$ for $24 \mathrm{~h}$.

\section{Phenotypic Characterization}

The probiotic candidates were grown on TSA at $32{ }^{\circ} \mathrm{C}$ for $24 \mathrm{~h}$, and the following characteristics of the isolates were tested: Gram reaction ( $\mathrm{KOH}$ method), shape and motility (phase contrast microscopy), cytochrome oxidase activity, catalase formation $\left(\mathrm{H}_{2} \mathrm{O}_{2}, 3 \% \mathrm{v} / \mathrm{v}\right)$ and glucose metabolism (O/F test).

\section{Qualitative Amylase Assay}

The isolated bacteria were inoculated on starch-agar plates, which were incubated at 32 ${ }^{\circ} \mathrm{C}$ for $24 \mathrm{~h}$ after Lugol's iodine solution [ $(\mathrm{w} / \mathrm{v}) 1 \%$ iodine in $2 \%$ potassium iodide] was poured over the plates. Extracellular amylase activities were detected as clear zones (halos) around the colonies, and the halo diameter was estimated using a calliper rule. The probiotic candidate presenting the largest halo around its colonies was chosen for further experiments.

\section{Genotypic Identification}

For DNA isolation, the selected strain was grown in TSB at $32{ }^{\circ} \mathrm{C}$ for $24 \mathrm{~h}$. Bacterial genomic DNA was isolated using the DNeasy® Tissue Kit (QIAGEN, CA, USA). Sequences of the $16 \mathrm{~S}$ rDNA gene were amplified using the universal bacterial primers $8 \mathrm{~F} \quad\left(5^{\prime}-\quad\right.$ AGAGTTTGATCCTTGGCTCAG-3'), 519R (5'GTATTACCGCGGCTGCTG-3'), 519F (5'-CAGCAGCCGCGGTAATAC-3') and 1492R (5'-GCYTACCTTGTTACGACTT-3'). PCR amplification was performed using a thermal cycler (2720, Applied Biosystems), with an initial denaturation step of $4 \mathrm{~min}$ at $95{ }^{\circ} \mathrm{C}$, followed by 35 cycles of $30 \mathrm{~s}$ at $95^{\circ} \mathrm{C}, 45 \mathrm{~s}$ at $50{ }^{\circ} \mathrm{C}$, and $1 \mathrm{~min}$ at $72{ }^{\circ} \mathrm{C}$, and a final extension step of $10 \mathrm{~min}$ at $72{ }^{\circ} \mathrm{C}$. Five microliters of the DNA extract was used for amplification in a total volume of $50 \mu$ containing 1.25 U of AmpliTaq DNA polymerase LD (Applied Biosystems, CA, USA). After purification, the PCR products were directly sequenced via the Sanger sequencing method using an ABI PRISM 350 Genetic Analyzer with the ABI BigDye Terminator version 3.1 Cycle Sequencing Kit (Applied Biosystems). The obtained DNA sequence was compared with the GenBank database of the National Center for Biotechnology Information (NCBI) using the 
BLAST program. A phylogenetic analysis was carried out using Molecular Evolutionary Genetics Analysis (MEGA) software version 4.0.

\section{Quantitative Amylase Assay}

The selected probiotic candidate was grown previously in $25 \mathrm{~mL}$ of TSB medium overnight at $32{ }^{\circ} \mathrm{C}$. A $0.5 \mathrm{~mL}$ aliquot of the liquid culture that was produced was subsequently inoculated into a flask with starch "liquid" medium, consisting of the starch-agar medium without the agar ${ }^{14,16,17}$. The culture flask was incubated at $32{ }^{\circ} \mathrm{C}$ for $24 \mathrm{~h}$. The cells were then harvested via centrifugation $\left(10000 \mathrm{~g}, 10 \mathrm{~min}, 4{ }^{\circ} \mathrm{C}\right)$, and the cell-free supernatant solution, which was used as the enzyme extract, was divided in aliquots in $15 \mathrm{~mL}$ Eppendorf tubes and stored at $-80{ }^{\circ} \mathrm{C}$ until analysis. Amylase activity was measured via the 3,5-dinitrosalicylic acid (DNS) method (Noelting and Bernfeld 1948). The reaction mixture consisted of $25 \mu 1$ of a $1 \%(\mathrm{w} / \mathrm{v})$ starch solution as a substrate, $25 \mu \mathrm{l}$ of Tris- $\mathrm{HCl}$ buffer [ $50 \mathrm{mmol}, \mathrm{pH} 8.5]$ and $50 \mu \mathrm{l}$ of the sampled enzyme extract. The reaction mixture was diluted with distilled water, and the absorbance at $550 \mathrm{~nm}$ was recorded using a microplate reader (Tecan Infinite 200). This method is based on the estimation of reduced sugar using maltose as the standard. Quantitative enzyme activity was expressed as units (U). One amylase unit was defined as the amount of enzyme per millilitre of culture filtrate releasing 1 microgram of reducing sugar per minute. Total protein determination was performed according to Bradford (1976) using bovine serum albumin as a standard. Specific activity was defined in terms of the enzyme activity units per mg of total protein.

\section{Enzymatic Characterization}

Enzymatic characterization of the potential probiotic strain was performed using the API ZYM system (bioMérieux, Marcy l'Etoile, France) according to the manufacturer's instructions.

\section{pH and Bile Tolerance}

The selected probiotic candidate was grown previously in TSB medium overnight at 32 ${ }^{\circ} \mathrm{C}$. The absorbance $(\mathrm{A} 600 \mathrm{~nm})$ was adjusted to $0.25 \pm 0.05$ to standardize the bacterial concentration $\left(10^{6}\right.$ to $\left.10^{7} \mathrm{CFU} \mathrm{mL} \mathrm{m}^{-1}\right)$. Aliquots of the bacterial suspension were centrifuged (5 $000 \mathrm{~g}, 10 \mathrm{~min}$ ) and resuspended in sterile PBS, which was adjusted to different $\mathrm{pH}$ levels $(2.0,3.0,4.0,5.0,6.0,7.0,8.0$ and 9.0) using $1 \% \mathrm{HCl}$ or $\mathrm{NaOH}$. The samples were then incubated for $2 \mathrm{~h}$ at $32{ }^{\circ} \mathrm{C}$. After each incubation period, the $\mathrm{OD}_{600}$ was measured, and the samples were serially diluted in sterile PBS to check the viable counts through plate counting using TSA. Tolerance to different bile concentrations was

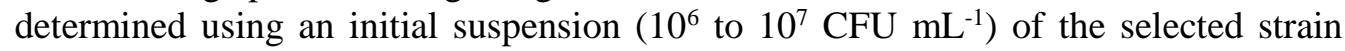
grown in TSB medium. Aliquots of the bacterial suspension were centrifuged (5000 $\mathrm{g}$, $10 \mathrm{~min}$ ) and then resuspended in sterile PBS with $0,0.15$ or $0.3 \%(\mathrm{w} / \mathrm{v})$ ox-bile. The samples were subsequently incubated for 2,4 and $8 \mathrm{~h}$ at $32{ }^{\circ} \mathrm{C}$. After each incubation period, the optical density was measured with a Genesis $10 \mathrm{~S}$ spectrophotometer (Thermo Scientific, MA, USA) at $600 \mathrm{~nm}$, and the samples were serially diluted in sterile PBS to check the viable counts through plate counting using TSA.

All in vitro experiments were executed in triplicate. 
Isolation of a probiotic bacterium

\section{RESULTS AND DISCUSSION}

Two of the 31 isolates obtained on (TSA)(2.2\% of the total), which came from the foregut of jundiá, were able to grow on Starch-agar medium and were therefore considered amylolytic. There was no observed mortality and no evidence of any harmful effects of either selected strain (designated M2 and E7 until proper identification) on jundiá juveniles, insofar as there was a total absence of any signs of disease following challenge via the intraperitoneal route. The M2 isolate was a Gram-negative, motile, rod-shaped bacterium, presenting non-fermentative glucose metabolism and catalase and oxidase positivity. The other isolate, E7, was a Gram-negative, motile, rod-shaped, glucose-fermenting, catalase- and oxidase-positive bacterium.

To assess the intensity of extracellular amylolytic enzyme production by the two isolated strains, a qualitative assay was conducted, and the halo-forming zone expressed in one culture (E7) reached $4 \mathrm{~mm}$, compared with the formation of a $0.5 \mathrm{~mm}$ halo by M2 strain. Considering this result, only the E7 strain was retained, as it showed better results regarding qualitative amylolytic enzyme production. Based on $16 \mathrm{~S}$ rDNA sequence analysis, the selected E7 strain was identified as Aeromonas veronii, with homology of $99 \%$.

Perhaps the most important criterion for selecting a potential probiotic is the ability of the bacterium to colonize the intestine of the host ${ }^{19,20}$. Based on adaptation allowing attachment to intestinal tissues, an adequate method for selecting a probiont is to extract it directly from the GI tract of the host ${ }^{21}$. This procedure does not limit the potential of the probiont merely to that of a transit strain ${ }^{22}$, even though transient bacteria can produce a positive influence in the host ${ }^{23}$.

The probiotic candidate isolated in this study probably belongs to the autochthonous microbiota, as neither of the two previous procedures performed to guarantee the removal of allochthonous bacteria impaired the ability of the strain to remain adhered tothe jundiá intestine. Another study showed the high adhesive ability of $A$. veronii in contact with the carp intestine under feeding or no-feeding conditions, which resulted in bacterial representativeness of $50 \%$ in both groups, in contrast to the other isolates ${ }^{24}$. This evidence corroborates the positive colonization status of $A$. veronii observed in the intestine of jundiá in the present study.

The genus Aeromonas is widely described as an emerging pathogen in aquatic organisms and humans ${ }^{25}$, but there is still a missing link between this virulent genus and a specific species or originating source. This situation becomes more obvious when one species is able to present multiple virulence factors without showing definite virulence potential ${ }^{26}$. The utilization of a bacterium from this exceptionally diverse genus as a probiotic can have positive effects as long as probiotic strains compete effectively. It is important to note that it would be highly desirable to obtain such strains belonging to the same pathogenic species that have been searching for nutrients and space to attach to a fish's intestine ${ }^{27}$. In the present study, A. veronii did not present any harmful effects in jundiá catfish, providing an initial basis for a mutualistic relationship ${ }^{28}$. Moreover, the high observed nucleotide variability ${ }^{29,30}$ and lack of an established pathogenic consensus about Aeromonads in humans ${ }^{25}$ leave many gaps to be filled to enable the use of such strains as possible probionts.

In this study, the amylase enzyme activity measured in $A$. veronii was $28.57 \mathrm{U} \mathrm{mL}^{-1}$, and the specific activity was $3.57 \mathrm{U} \mathrm{mg}^{-1}$. In addition, an enzymatic profile determined using the API ZYM system was established for the probiotic candidate and is summarized in Table 1.

API ZYM is a semi-quantitative assay for screening 19 hydrolytic enzymes, among which eight carbohydrases are considered. However, only N-acetyl- $\beta$-glucosaminidase presented positive activity in A. veronii in the present study. All of the other carbohydrases presented negative activity, including $\alpha$-glucosidase, which decreases the range of susceptible carbohydrates to allow complete degradation by this exogenous 
enzyme for aquaculture feed usage, as $\alpha$-glucosidase is adapted to hydrolyse many carbohydrates, such as $\alpha$-D-glucosides ( $\rho$-nitrophenyl- $\alpha$-D-glucoside and methyl- $\alpha-D-$ glucoside), oligosaccharides (maltodextrins), and polysaccharides (amylose, amylopectin, and glycogen) ${ }^{31}$. On the other hand, the host itself may secrete this $\alpha$ glucosidase enzyme, thus avoiding the limitation imposed by $A$. veronii. This hypothesis is supported by the fact that the digestion of jundiá is improved by the inclusion of ingredients from plant sources with higher levels of maltose, instead of starch, within tested diets ${ }^{32}$. Moreover, the promising synergistic effect of the combination of $\alpha$ glucosidase and $\alpha$-amylase resulted in starch granule hydrolysis that was 8 to 11 times greater than the sum of the hydrolysis achieved by two enzymes alone ${ }^{31}$.

Table 1 Enzymatic profile (API ZYM test) of A. veronii probiotic candidate

\begin{tabular}{cc}
\hline Biochemical test & A. veronii \\
\hline Alkaline phosphatase & - \\
Esterase (C4) & + \\
Esterase lipase (C8) & + \\
Lipase (C4) & - \\
Leucine arylamidase & - \\
Valine arylamidase & - \\
Cystine arylamidase & - \\
Trypsin & + \\
$\alpha-$ Chymotrypsin & + \\
Acid phosphatase & + \\
$\alpha$ Naphthol-AS-BI-phosphohydrolase & - \\
$\beta-$ Galactosidase & - \\
$\beta-$ Glucuronidase & - \\
$\alpha-$ Glucosidase & - \\
$\beta-$ Glucosidase & - \\
$\alpha-$-acetyl-b-glucosaminidase & + \\
$\alpha-$ Funnosidase & - \\
\hline
\end{tabular}

The selected strain presented high tolerance to acidic conditions (Fig. 1). Resistance of the isolate was observed after exposure to acidified media, except at a $\mathrm{pH}$ of 2 . However, the greatest tolerance of $A$. veronii occurred between $\mathrm{pH} 5$ and 9. The tolerance of $A$. veronii in the presence of bile salts was also analysed, and the results showed that it was able to survive at both of the concentrations tested (0.15 and 0.3\%) (Fig. 2). Our findings showed that $A$. veronii presents $\mathrm{pH}$ and bile tolerance, starting at exposure to a $\mathrm{pH}$ of 3 and in all of the tested concentrations of bile salts $(0.15 \%-0.3 \%)$. Despite the great importance attributed to probiont gastric survival thus far, studies have shown that it is possible to achieve sufficient viability of acid-sensitive strains in the stomach by inducing $\mathrm{pH}$ elevation through the addition of feed ${ }^{33}$ or via offering physical protection mechanisms to the microorganisms ${ }^{34}$. In this context, an essential criterion for the selection of probiotics, in addition to bile salt tolerance ${ }^{22,35}$, should be the ability to tolerate an alkaline $\mathrm{pH}^{34}$ close to 8.5 , which occurs in the region posterior to the pylorus ${ }^{36}$, thus enabling probiont survival and colonization of the small intestine. According to this scenario, the present study showed promising results, as A. veronii was able tolerate 
$\mathrm{pH}$ levels ranging from neutral up to $\mathrm{pH}$, which was the maximum level tested in this study.

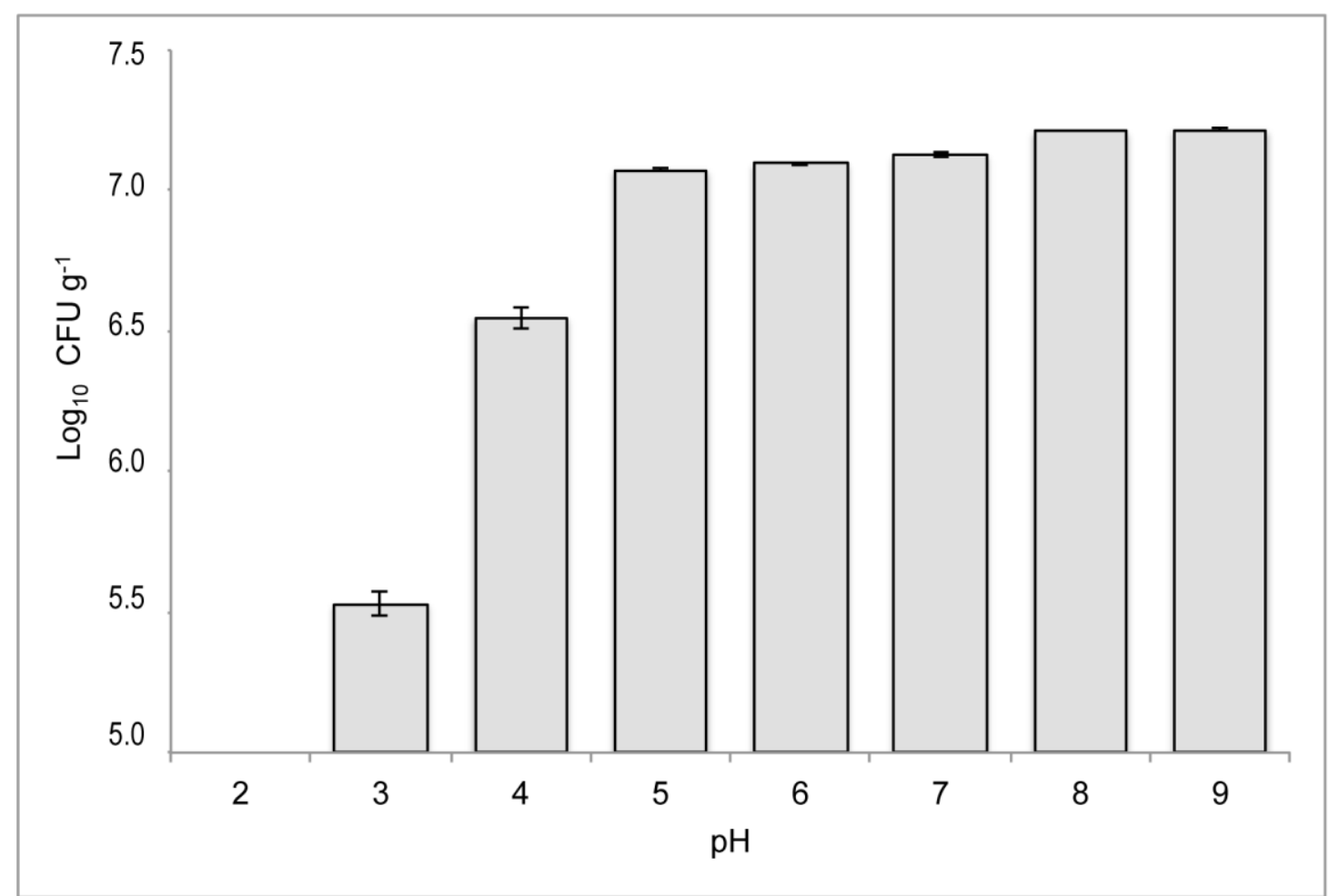

Figure 1 - pH tolerance of $A$. veronii in TSB after $2 \mathrm{~h}$ of incubation. Results are expressed as $\log _{10} \mathrm{CFU}_{\mathrm{g}}{ }^{-1}$ of bacteria survival in different $\mathrm{pH}$. Each value is the mean $\pm \mathrm{SEM}$.

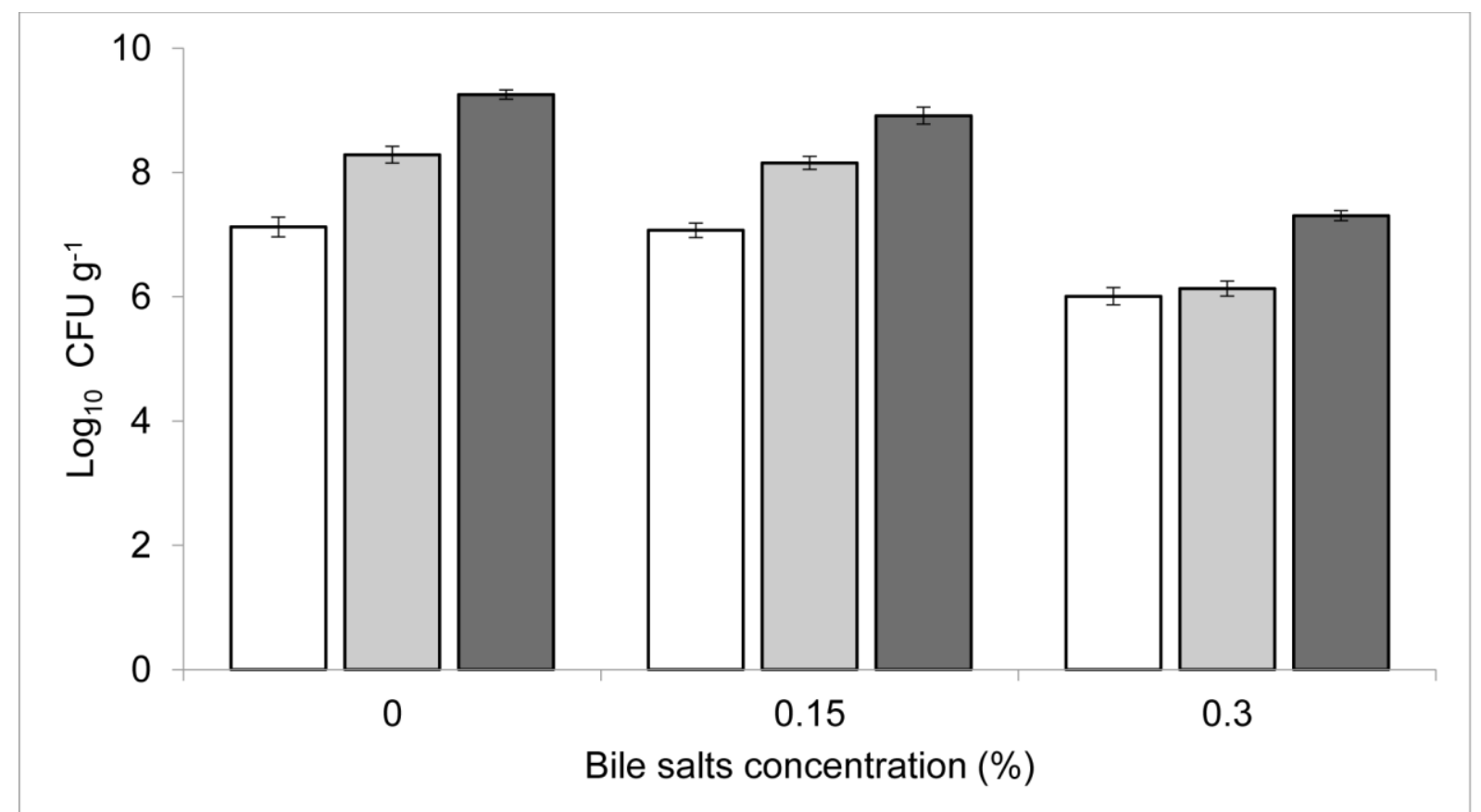

Figure 2 - Bile salt tolerance of A. veronii in TSB after $2 \mathrm{~h} \mathrm{(} \square), 4 \mathrm{~h} \mathrm{(} \square)$ and $8 \mathrm{~h} \mathrm{(} \square)$ of incubation. Results are expressed by Log10 CFU g-1 of bacteria survival in different concentrations of bile salts (\%). Each value is the mean \pm SEM. 
In conclusion, the results of this study demonstrated the potential of the isolated $A$. veronii strain to improve the digestion process of jundiá, by providing exogenous enzymes for the breakdown and absorption of nutrients. The bacterium isolated from the intestinal tract of jundiá was able to produce enzymes that are commonly used in the digestion process, including phosphatase, lipase, esterase, peptidase and carbohydrase. Another favourable feature of A. veronii is its ability to survive stress exerted by a range of $\mathrm{pH}$ and bile salt conditions. Efforts to improve the utilization of enzyme-producing bacterial isolates as probiotics in feed formulated with higher contents of carbohydrates are essential to reduce costs and decrease dependence on ingredients of animal origin, thereby enhancing the sustainability of aquaculture.

\section{ACKNOWLEDGEMENTS}

Thanks are due to the Brazilian Federal Agency for the Support and Evaluation of Graduate Education (CAPES) and to the National Council for Scientific and Technological Development $(\mathrm{CNPq})$ for providing fellowships to the first and last authors, respectively.

\section{REFERENCES}

1- Glencross BD, Booth M, Allan GL. A feed is only as good as its ingredients? a review of ingredient evaluation strategies for aquaculture feeds. Aquac Nutr. 2007; 13(1): 17-34.

2- Tacon AGJ, Metian M. Global overview on the use of fish meal and fish oil in industrially compounded aquafeeds: Trends and future prospects. Aquaculture. 2008; 285(1-4): 146-58.

3- Krogdahl $\AA$, Hemre G, Mommsen T. Carbohydrates in fish nutrition: digestion and absorption in postlarval stages. Aquac Nutr. 2005; 11(2): 103-22.

4- Hemre G-I, Mommsen TP, Krogdahl A. Carbohydrates in fish nutrition: effects on growth, glucose metabolism and hepatic enzymes. Aquac Nutr. 2002; 8(3): 175-94.

5- Gatlin III DM. Principles of Fish Nutrition. South Reg Aquac Cent. 2010; (5003): 1-8.

6- National Research Council of the National Academies. Nutrient requirements of fish and shrimp . Whashington, D.C.: National Academies Press; 2011.

7- Oliveira Filho PRC de, Fracalossi DM. Coeficientes de digestibilidade aparente de ingredientes para juvenis de jundiá. (Apparent digestibility coefficients of ingredients for juvenile of catfish jundiá). Rev Bras Zootec. 2006; 35(4): 1581-7.

8- Moro GV, Camilo RY, Moraes G, Fracalossi DM. Dietary non-protein energy sources: growth, digestive enzyme activities and nutrient utilization by the catfish jundiá, Rhamdia quelen. Aquac Res. 2010 ; 41(3): 394-400.

9- Rodrigues APO, Gominho-Rosa MDC, Cargnin-Ferreira E, De Francisco A, Fracalossi DM. Different utilization of plant sources by the omnivores jundiá catfish (Rhamdia quelen) and Nile tilapia (Oreochromis niloticus). Aquac Nutr. 2012; 18(1): 65-72.

10- Ring $\varnothing$ E, Strom E, Tabachek J. Intestinal microflora of salmonids : a review. Aquac Res. 1995; 26: 773-89.

11- Yanbo W, Zirong X. Effect of probiotics for common carp (Cyprinus carpio) based on growth performance and digestive enzyme activities. Anim Feed Sci Technol. 2006; 127(3-4): $283-92$.

12- Gatesoupe FJ. Probiotic and formaldehyde treatments of Artemia nauplii as food for larval pollack, Pollachius pollachius. Aquaculture. 2002; 212(1-4): 347-60.

13- Lara-Flores M, Olvera-Novoa MA, Guzmán-Méndez BE, López-Madrid W. Use of the bacteria Streptococcus faecium and Lactobacillus acidophilus, and the yeast Saccharomyces cerevisiae as growth promoters in Nile tilapia (Oreochromis niloticus). Aquaculture. 2003; 216(1-4): 193-201.

14- Ray AK, Roy T, Mondal S, Ring $\varnothing$, E. Identification of gut-associated amylase, cellulase and protease-producing bacteria in three species of Indian major carps. Aquac Res. 2010; 1462 9.

15- Das KM, Tripathi SD. Studies on the Digestive Enzymes of grass carp, Ctenopharyngodon idella (Val.). Aquaculture. 1991; 92: 21-32.

16- Bairagi A, Ghosh KS, Sen SK, Ray AK. Enzyme producing bacterial flora isolated from 
Isolation of a probiotic bacterium

fish digestive tracts. Aquac Int. 2002; 10: 109-21.

17- Mondal S, Roy T, Sen SK, Ray AK. Distribution of enzyme-producing bacteria in the digestive tracts of some freshwater fish. Acta Ichthyol Piscat. 2008; 38(1): 1-8.

18- Bradford MM. A rapid and sensitive method for the quantitation of microgram quantities of protein utilizing the principle of protein-dye binding. Anal Biochem. 1976; 72: 248-54.

19- Merrifield DL, Dimitroglou A, Foey A, Davies SJ, Baker RTM, Bøgwald J, et al. The current status and future focus of probiotic and prebiotic applications for salmonids. Aquaculture. 2010; 302(1-2): 1-18.

20- Nayak SK. Probiotics and immunity: A fish perspective. Fish Shellfish Immunol. 2010; 29(1): 2-14.

21- Carnevali O, Zamponi MC, Sulpizio R, Rollo A, Nardi M, Orpianesi C, et al. Administration of probiotic strain to improve sea bream wellness during development. Aquac Int. 2004; 12(4-5): 377-86.

22- O'Sullivan DJ. Screening of intestinal microflora for effective probiotic bacteria. J Agric Food Chem. 2001; 49(4): 1751-60.

23- Isolauri E, Ouwehand AC. Probiotics. Best Pract Res Clin Gastroenterol. 2004; 18(2): 299-313.

24- Namba A, Mano N, Hirose H. Phylogenetic analysis of intestinal bacteria and their adhesive capability in relation to the intestinal mucus of carp. J Appl Microbiol. 2007; 102(5): $1307-17$.

25- Janda JM, Abbott SL. The genus Aeromonas: Taxonomy, pathogenicity, and infection. Clin Microbiol Rev. 2010; 23(1): 35-73.

26- Martino ME, Fasolato L, Montemurro F, Novelli E, Cardazzo B. Aeromonas spp.: ubiquitous or specialized bugs? Environ Microbiol. 2014; 16(4): 1005-18.

27- Gram L, Ringø E. Chapter 17 Prospects of fish probiotics. Biol Grow Anim. 2005; 2(C): 379-417.

28- Ray AK, Ghosh K, Ring $\varnothing$ E. Enzyme-producing bacteria isolated from fish gut: a review. Aquac Nutr. 2012; 18(5): 465-92.

29- Alperi A, Martínez-Murcia AJ, Ko WC, Monera A, Saavedra MJ, Figueras MJ. Aeromonas taiwanensis sp. nov. and Aeromonas sanarellii sp. nov., clinical species from Taiwan. Int J Syst Evol Microbiol.2010; 60(9): 2048-55.

30- Alperi A, Martínez-Murcia AJ, Monera A, Saavedra MJ, Figueras MJ. Aeromonas fluvialis sp. nov., isolated from a spanish river. Int J Syst Evol Microbiol. 2010; 60(1): 72-7.

31- Sun Z, Henson C a. Degradation of Native Starch Granules by Barley alpha-Glucosidases. Plant Physiol. 1990; 94(1): 320-7.

32- Gominho-Rosa MDC, Rodrigues APO, Mattioni B, de Francisco A, Moraes G, Fracalossi DM. Comparison between the omnivorous jundiá catfish (Rhamdia quelen) and Nile tilapia (Oreochromis niloticus) on the utilization of dietary starch sources: Digestibility, enzyme activity and starch microstructure. Aquaculture. 2015; 435: 92-9.

33- Conway PL, Gorbach SL, Goldin BR. Survival of lactic acid bacteria in the human stomach and adhesion to intestinal cells. J Dairy Sci. 1987; 70(1): 1-12.

34- Huang Y, Adams MC. In vitro assessment of the upper gastrointestinal tolerance of potential probiotic dairy propionibacteria. Int J Food Microbiol. 2004; 91(3): 253-60.

35- Balcázar JL, Vendrell D, de Blas I, Ruiz-Zarzuela I, Muzquiz JL, Girones O. Characterization of probiotic properties of lactic acid bacteria isolated from intestinal microbiota of fish. Aquaculture. 2008 ; 278: 188-91.

36- Deguara S, Jauncey K, Agius C. Enzyme activities and $\mathrm{pH}$ variations in the digestive tract of gilthead sea bream. J Fish Biol. 2003; 62(5): 1033-43. 